Original Research Paper

\title{
Sosialisasi DAGUSIBU Untuk Meningkatkan Rasionalitas Penggunaan Obat Bagi Masyarakat Kerandangan Desa Senggigi
}

\author{
Wahida Hajrin $^{1}$, Windah Anugrah Subaidah ${ }^{2}$, Yohanes Juliantoni ${ }^{3}$ \\ ${ }^{1}$ Program Studi Farmasi Fakultas Kedokteran, Universitas Mataram, Mataram, Indonesia; \\ ${ }^{2}$ Program Studi Farmasi Fakultas Kedokteran, Universitas Mataram, Mataram, Indonesia; \\ ${ }^{3}$ Program Studi Farmasi Fakultas Kedokteran, Universitas Mataram, Mataram, Indonesia;
}

DOI: https://doi.org/10.29303/jpmpi.v3i2.492

Sitasi : Hajrin, W., Subaidah, W. A., \& Juliantoni, Y. (2020). Sosialisasi DAGUSIBU Untuk Meningkatkan Rasionalitas Penggunaan Obat Bagi Masyarakat Kerandangan Desa Senggigi. Jurnal Pengabdian Magister Pendidikan IPA, 3(2)

\author{
Article history \\ Received: 19 September 2020 \\ Revised: 14 Oktober 2020 \\ Accepted: 19 November 2020 \\ *Corresponding Author: \\ Wahida Hajrin, \\ Universitas Mataram, Mataram, \\ Indonesia; \\ Email: \\ wahida08farm@gmail.com
}

\begin{abstract}
Senggigi village community has limitations in obtaining information about health, one of which is DAGUSIBU. DAGUSIBU is a way to get, use, store and dispose of medicines properly. The aim of this socialization was to inform about DAGUSIBU to the community so that medicines can be used rationally. The method used in the socialization is the delivery of material and direct examples related to the use of medicines that require special methods. The participants were very enthusiastic to attend the socialization, as evidenced by the many questions related to DAGUSIBU raised. This socialization increased participant's knowledge about DAGUSIBU, they understand how to get, use, store and dispose of medicines in the right way.
\end{abstract}

Keywords: DAGUSIBU; Health; Medicine; Socialization

\section{Pendahuluan}

Penggunaan obat tidak dapat dipisahkan dengan terapi penyakit, karena obat dapat digunakan dalam pencegahan penyakit, pengobatan penyakit, diagnostik, maupun pemeliharaan kesehatan. Hal ini menyebabkan pemahaman tentang obat sangat penting bagi masyarakat untuk dapat memperoleh manfaat yang tepat dari penggunaan obat. Menurut penelitian yang dilakukan oleh Syafitri et al., penggunaan obat parasetamol dengan rasional dalam swamedikasi dipengaruhi oleh tingkat pengetahuan (Syafitri et al., 2018). Tingkat pengetahuan tentang obat salah satunya dapat dipengaruhi oleh faktor pendidikan (Harahap et al., 2017).

DAGUSIBU merupakan jargon dalam kampanye Gerakan Keluarga Sadar Obat. DAGUSIBU merupakan singkatan dari "DApatkan, GUnakan, SImpan, dan BUang” obat dengan benar. DAGUSIBU merupakan konsep mendasar kefarmasian dalam penggunaan obat secara rasional oleh pasien. Pengetahuan DAGUSIBU sangat penting bagi masyarakat untuk meningkatkan rasionalitas penggunaan obat. Penelitian yang dilakukan oleh Sambara et al. tentang pengetahuan dan pemahaman masyarakat Kupang tentang cara penggunaan obat menunjukkan bahwa $51,48 \%$ tidak 
mengetahui dan tidak memahami cara penggunaan obat dengan benar (Sambara et al., 2014). Menurut Pujiastuti dan Kristiani, sosialisasi DAGUSIBU dapat meningkatkan pemahaman masyarakat dalam pengelolaan obat secara tepat (Pujiastuti and Kristiani, 2019). Edukasi dan simulasi DAGUSIBU juga dapat meningkatkan pengetahuan masyarakat untuk menciptakan keluarga sadar obat (Suryoputri and Sunarto, 2019). Pada penelitian yang dilakukan oleh Meriati, cara penggunaan dan pemilihan obat batuk dalam swamedikasi dapat meningkat dengan adanya sosialisasi pada masyarakat (Meriati et al., 2013).

Desa Senggigi merupakan salah satu desa di kecamatan Batu Layar kabupaten Lombok Barat, yang memiliki jumlah penduduk yang banyak dengan daerah yang cukup luas. Jumlah penduduk di desa Senggigi adalah \pm 4.653 jiwa pada tahun 2016, terbagi dalam 1.643 KK (Pemerintah Desa Senggigi, 2018). Tingginya angka jumlah penduduk dengan daerah yang luas tersebut tidak sebanding dengan jumlah sarana kesehatan yang ada, sehingga informasi tentang kesehatan, obat, dan pengobatan yang diperoleh masyarakat sangat terbatas. Keterbatasan tenaga kefarmasian menyebabkan ketidakmampuan dalam sosialisasi tentang obat kepada masyarakat. Di puskesmas hanya terdapat tenaga teknis kefarmasian, sehingga kemampuan terjun ke masyarakat sangat terbatas.

Berdasarkan latar belakang tersebut, perlu dilakukan sosialisasi DAGUSIBU untuk memenuhi kebutuhan masyarakat akan informasi kesehatan dan pengobatan yang langsung dilakukan oleh apoteker untuk menunjang terwujudnya peningkatan derajat kesehatan masyarakat. DAGUSIBU merupakan salah satu solusi untuk meningkatkan pemahaman masyarakat akan obat dan pengobatan dalam menghadapi permasalahan kesehatan sehari-hari.

\section{Metode}

Pelaksanaan kegiatan dilakukan dengan metode sosialisasi atau penyuluhan. Pemberian informasi kepada peserta sosialisasi dilakukan dengan media power point dan leaflet. Selain itu, diberikan pula contoh langsung dengan menunjukkan kemasan obat untuk meningkatkan pemahaman peserta sosialisasi terhadap materi yang disampaikan.

Pelaksanaan kegiatan pengabdian pada masyarakat ini dibagi dalam tiga tahap, yaitu tahap persiapan, tahap pelaksanaan, dan tahap evaluasi. Tahap persiapan dilakukan pada bulan Juli hingga Agustus 2019. Pada tahap ini dilakukan koordinasi dengan pemerintah desa Senggigi untuk menentukan waktu dan tempat diadakannya sosialisai. Pelaksanaan kegiatan sosialisasi dilakukan pada tanggal 28 Agustus 2019. Peserta sosialisasi adalah ibu-ibu PKK dan kader Posyandu desa Senggigi. Pemberian materi diselingi dengan game untuk memperoleh timbal balik dari peserta sosialisasi. Game diberikan di awal, tengah, dan akhir sosialisasi. Evaluasi dilakukan melalui pretest dan posttest sebagai dasar penilaian terhadap pemahaman peserta sosialisasi terhadap materi yang diberikan. Pemberian pretest dan posttest dilakukan secara tulisan, sebagai salah satu dokumen hasil pengabdian pada masyarakat.

Analisis data dilakukan dengan skoring pada tiap soal pretest dan posttest, skor 1 (satu) untuk jawaban benar dan skor 0 (nol) untuk jawaban salah. Rata-rata persentase jawaban benar pada semua 
Hajrin et al, Jurnal Pengabdian Magister Pendidikan IPA, 2020, 3 (2): 137-143

peserta ditentukan dan dibandingkan antara nilai pretest dan nilai posttest.

\section{Hasil dan Pembahasan}

Kegiatan pengabdian kepada masyarakat ini bertujuan untuk memberikan informasi dan edukasi kepada masyarakat melalui kegiatan sosialisasi tentang DAGUSIBU, yaitu cara mendapatkan obat, cara menggunakan obat, cara menyimpan obat, dan cara membuang obat dengan baik dan benar. Kegiatan ini dirasa penting karena setiap orang pasti mengkonsumsi obat-obatan. Obat membutuhkan penanganan khusus untuk menjaga mutu dan khasiat serta keamanannya bagi pasien. Penanganan yang tepat dibutuhkan untuk menjaga rasionalitas penggunaan obat bagi pasien (BPOM RI, 2015).

Sebelum kegiatan dilakukan, terlebih dahulu dilakukan koordinasi dengan pemerintah desa Senggigi. Koordinasi ini penting dilakukan untuk menyampaikan tujuan dan luaran yang diharapkan dari kegiatan sosialisasi ini. Pemerintah desa Senggigi mendukung penuh adanya sosialisasi DAGUSIBU karena pemerintah merasa kurangnya infomasi dan edukasi bagi masyarakat tentang obatobatan dan kesehatan. Selain itu, koordinasi juga dilakukan terkait penentuan waktu dan lokasi sosialisasi. Kendala yang dihadapi pada saat penentuan waktu sosialisasi adalah padatnya kegiatan desa pada saat yang bersamaan, sehingga membutuhkan koordinasi yang lebih lama untuk menentukan waktu yang tepat. Lokasi sosialisasi ditetapkan di balai desa Senggigi, bersebelahan dengan kantor desa.

Sosialisasi DAGUSIBU dilakukan pada tanggal 28 Agustus 2019, dengan melibatkan mahasiswa
e-ISSN: 2655-5263

sebanyak tujuh orang. Mahasiswa dilibatkan sejak proses persiapan yaitu saat pembuatan banner dan leaflet, pada saat pelaksanaan kegiatan sosialisasi yaitu pendaftaran peserta, sebagai MC, dan sebagai pengisi materi, hingga setelah kegiatan selesai terkait admnistrasi. Mahasiswa memiliki andil yang besar dalam penyelenggaraan sosialisasi ini. Hal ini dilakukan untuk melatih mahasiswa dalam memberikan informasi dan mengedukasi masyarakat, khususnya terkait obat yang merupakan bidang ilmu di Farmasi.

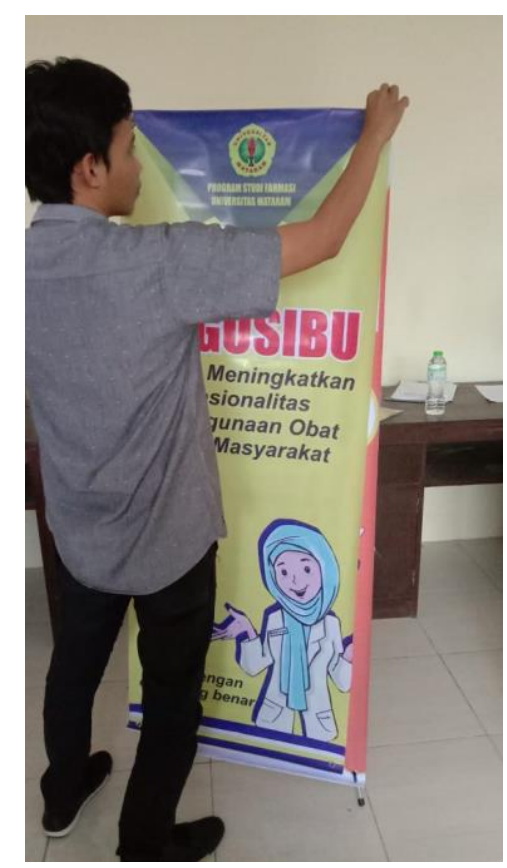

Gambar 1. Proses persiapan : pembuatan $x$-banner

Kegiatan sosialisasi diawali dengan sambutan dari bapak Kepala Desa untuk memberikan arahan sekaligus membuka acara. Acara dimulai pada pukul 09.30 WITA, yang seharusnya dijadwalkan pada jam 08.30 WITA. Keterlambatan ini disebabkan oleh adanya kendala teknis, selain menunggu kedatangan peserta. Peserta yang hadir diminta untuk mengisi absensi dan menjawab soal pretest untuk mengetahui tingkat pemahaman peserta 
Hajrin et al, Jurnal Pengabdian Magister Pendidikan IPA, 2020, 3 (2): 137-143 terkait DAGUSIBU. Penyampaian materi sosialisasi dilakukan selama kurang lebih 1 jam. Penyampaian materi diselingi dengan game yang meningkatkan semangat peserta untuk mengikuti kegiatan. Materi yang disampaikan berupa cara mengetahui obat layak pakai, cara mendapatkan obat dengan benar, cara menyimpan obat dengan benar, dan cara membuang obat dengan benar.

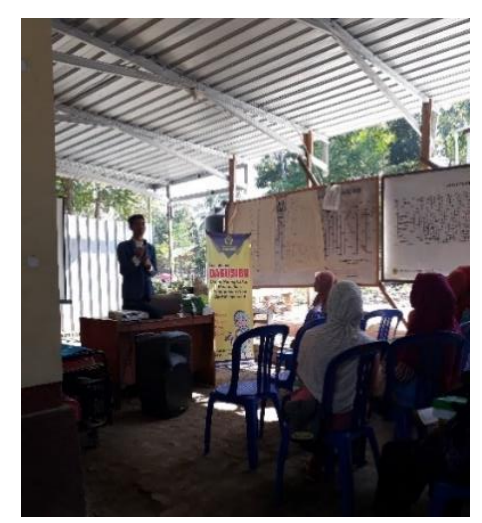

Gambar 2. Peran mahasiswa saat kegiatan sosialisasi berlangsung

Cara mendapatkan obat dengan benar disosialisasikan kepada masyarakat agar masyarakat dapat memperoleh obat yang tepat di tempat yang tepat. Apotek, puskesmas, dan rumah sakit merupakan sarana kesehatan yang dapat menjamin masyarakat dalam memperoleh obat legal yang tepat sesuai kondisi kesehatannya. Masyarakat juga diberikan informasi tetang penggolongan obat, yaitu obat bebas, obat bebas terbatas, obat keras, dan narkotika. Materi tentang cara mengetahui obat layak pakai mengedukasi masyarakat tentang cara mengetahui waktu kadaluwarsa obat dan cara mengetahui ciri-ciri obat rusak secara fisik. Sebagai contoh, ciri-ciri obat bentuk cair yang sudah tidak layak konsumsi antara lain berubah warna, bau, dan rasa, mengental, mengendap, memisah, mengeras,

\section{e-ISSN: 2655-5263}

segel kemasan rusak, dan atau kemasan lembab (berembun) (BPOM RI, 2019a).

Cara menggunakan obat dengan tepat terkait dengan keberhasilan terapi. Aturan pakai obat, frekuensi penggunaan obat, durasi penggunaan obat, dan cara penggunaan obat sediaan khusus seperti tetes mata diinformasikan kepada masyarakat untuk memperbaiki kesalahan penggunaan yang selama ini terjadi di masyarakat. Menurut Kristina et al., pengetahuan tentang cara penggunaan obat yang tepat berpengaruh terhadap rasionalitas penggunaan obat (Kristina et al., 2007). Penelitian yang dilakukan oleh Harahap et al. menunjukkan bahwa pengetahuan pasien tentang obat di tiga apotek di kota Penyabungan yang tergolong sedang berpengaruh pada penggunaan obat swamedikasi yang tidak rasional, yaitu mencapai 40,6\% (Harahap et al., 2017).

Cara menyimpan obat yang salah dapat meyebabkan kerusakan pada obat sehingga masyarakat harus mengetahui cara yang tepat untuk menyimpan masing-masinng sediaan. Kondisi dan lama penyimpanan obat dapat mempengaruhi mutu obat (Lestari, 2013). Salah satu kondisi yang berpengaruh adalah suhu penyimpanan (Karlida and Musfiroh, 2017).

Cara membuang obat yang benar harus diinformasikan kepada masyarakat. Hal ini karena obat-obat kadaluwarsa dan obat rusak, maupun kemasan obat yang tidak dimusnahkan dengan benar akan dimanfaatkan oleh pihak yang tidak bertanggung jawab sebagai obat palsu dengan mengganti tanggal kadaluwarsa obat (BPOM RI, 2019b). Sebagai contoh, kemasan botol obat dapat dibuang dengan membuang sisa isi obat yang 
diencerkan menggunakan air dan melepaskan label pada kemasan obat untuk mencegah penggunaan kembali.

Peserta sosialisasi sangat antusias dengan materi yang disampaikan. Peserta memperhatikan dengan baik setiap materi yang disampaikan dan menanyakan jika ada hal yang belum dipahami. Pertanyaan yang disampaikan terkait dengan penggunaan obat yang mereka lakukan sehari-hari.

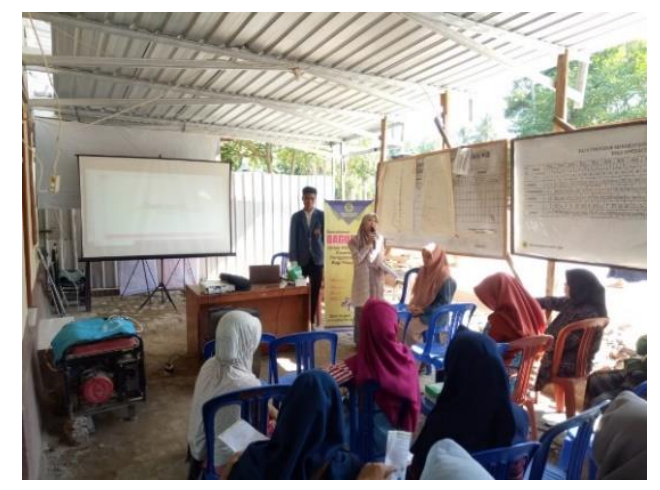

Gambar 3. Sesi tanya jawab

Evaluasi hasil kegiatan pengabdian pada masyarakat menunjukkan adanyapeningkatan pengetahuan peserta sosialisasi terhadap materi dagusibu. Berdasarkan kategori soal DA (dapatkan), GU (gunakan), SI (simpan), dan BU (buang) obat dengan benar diperoleh data seperti terlihat pada gambar 4.

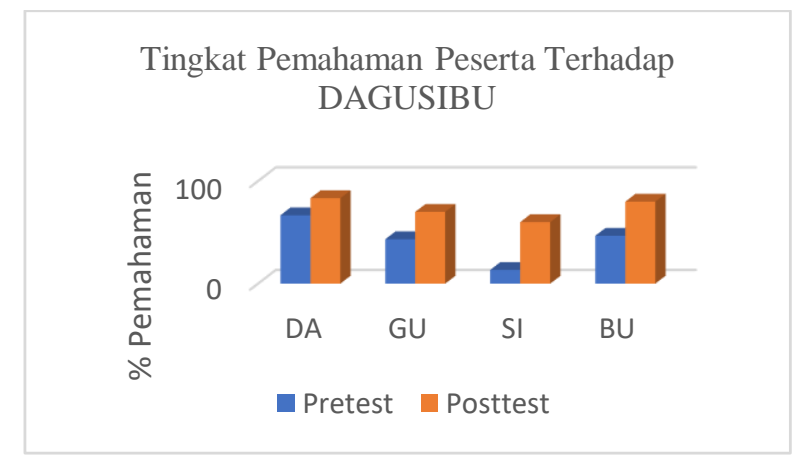

Gambar 4. Grafik persentase pemahaman peserta pada masing-masing kategori soal sebelum dan setelah sosialisasi
Berdasarkan hasil tersebut terlihat bahwa terjadi peningkatan persentase pemahaman peserta sosialisasi baik pada kategori soal cara mendapatkan (DA), menggunakan (GU), menyimpan (SI), maupun membuang (BU) obat dengan benar. Ratarata tingkt pemahaman peserta pada semua soal adalah sebesar $45,83 \%$ pada pretest dan $73,33 \%$ pada posttest. Hasil ini kemudian dianalisis menggunakan statistik untuk mengetahui tingkat perbedaan hasil pretest dan posttest. Berdasarkan uji Kruskall-Wallis diperoleh hasil bahwa nilai pretest dan posttest memiliki perbedaan yang signifikan ( $p$ value $=0,000$ ). Hal ini menunjukkan bahwa terdapat peningkatan pemahaman peserta tentang DAGUSIBU setelah dilakukan sosialisasi. Sosialisasi singkat yang dilakukan dapat meningkatkan pengetahuan peserta sosialisasi, namun dibutuhkan kegiatan-kegiatan lanjutan yang lebih intens untuk benar-benar menanamkan ketepatan pengelolaan obat oleh masyarakat dalam kehidupan sehari-sehari untuk mencapai tujuan terapi yang aman, berkhasiat, dan bermutu.

\section{Kesimpulan}

Peserta sosialisasi memahami materi sosialisasi DAGUSIBU yang diberikan, dibuktikan dengan peningkatan pengetahuan sesudah sosialisasi.

\section{Saran}

Perlu peningkatan pemahaman secara kontinyu bagi masyarakat dengan metode lain yang lebih intens, misalnya dengan focus group discussion atau dengan pendampingan secara kontinyu hingga 
Hajrin et al, Jurnal Pengabdian Magister Pendidikan IPA, 2020, 3 (2): 137-143

terbentuk keluarga sadar obat melalui penerapan

DAGUSIBU yang tepat dalam kehidupan seharihari.

\section{Ucapan Terima Kasih}

Penulis mengucapkan terima kasih kepada Universitas Mataram yang telah memberi dukungan financial terhadap penelitian ini.

\section{Daftar Pustaka}

BPOM RI, 2019a. Waspada obat kadaluwarsa. Pusat Data dan Informasi Obat dan Makanan. https://www.pom.go.id/new/view/more/beri ta/16697/Waspada-Obat-Kedaluwarsa.

BPOM RI, 2019b. Aksi nasional pemberantasan obat illegal dan penyalahgunaan obat-ayo buang sampah obat. Humas dan DSP Badan POM

RI.

https://www.pom.go.id/new/view/more/ pers/491/---Aksi-Nasional-

Pemberantasan-Obat-Ilegal-Dan-

Penyalahgunaan-Obat-----Ayo-Buang-

$\underline{\text { Sampah-Obat---.html }}$

BPOM RI, 2015. Pedoman umum IONI. Pusat Informasi Obat Balai Pengawasan Obat dan Makanan.

http://pionas.pom.go.id/ioni/pedomanumum.

Harahap, N.A., Khairunnisa, K., Tanuwijaya, J., 2017. Patient knowledge and rationality of self-medication in three pharmacies of Panyabungan City, Indonesia. Jurnal Sains Farmasi \& Klinis, (2), 3, 186. https://doi.org/10.29208/jsfk.2017.3.2.124

Karlida, I., Musfiroh, I., 2017. Review: suhu penyimpanan bahan baku dan produk farmasi di gudang industri farmasi. Farmaka, (4), 15, 58-67.
e-ISSN: 2655-5263

Kristina, S.A., Prabandari, Y.S., Sudjaswadi, R., 2007. Perilaku pengobatan sendiri yang rasional pada masyarakat. Berita Kedokteran Masyarakat, (4), 23, 176183.

Lestari, N., 2013. Pengaruh kondisi penyimpanan obat terhadap kualitas tablet vitamin $\mathrm{C}$ di Puskesmas Kecamatan Pontianak Kota, Skripsi. Universitas Tanjungpura, Pontianak.

Meriati, N.W.E., Goenawi, L.R., Wiyono, W., 2013. Dampak penyuluhan pada pengetahuan masyarakat terhadap pemilihan dan penggunaan obat batuk swamedikasi di Kecamatan Malalayang. Jurnal Ilmiah Farmasi Pharmacon, (3), 2, 100-103.

Pemerintah Desa Senggigi, 2018. Profil masyarakat desa Senggigi. Desa Senggigi Kecamatan Batu Layar Kabupaten Lombok Barat. http://mppldesasenggigi.byethost24.com/in dex.php/first/artikel/34.

Pujiastuti, A., Kristiani, M., 2019. Sosialisasi DAGUSIBU (Dapatkan, Gunakan, Simpan, Buang) obat dengan benar pada guru dan karyawan SMA Theresiana I Semarang. Indonesian Journal of Community Services, (1) 1 , 62-72. https://doi.org/10.30659/ijocs.1.1.62-72

Sambara, J., Yuliani, N.N., Bureni, Y., 2014. Tingkat pengetahuan dan pemahaman masyarakat tentang penggunaan obat yang benar di Kota Kupang Tahun 2014. Jurnal Info Kesehatan, (1), 12, 684-702.

Suryoputri, M.W., Sunarto, A.M., 2019. Pengaruh edukasi dan simulasi Dagusibu obat terhadap peningkatan keluarga sadar obat di Desa Kedungbanteng Banyumas. Jurnal Aplikasi Teknik dan Pengabdian Masyarakat, (1), 3, 51-55. 
Syafitri, I.N., Hidayati, I.R., Pristianty, L., 2018. Hubungan tingkat pengetahuan terhadap penggunaan obat parasetamol rasional dalam swamedikasi. Jurnal Farmasi Dan Ilmu Kefarmasian Indonesia, (1), 4, 19-26. https://doi.org/10.20473/jfiki.v4i12017.1926 